\title{
WOMEN AND DIVORCE: LEGAL JUSTICE STUDY OF SOCIETAL AND JUDICIAL PERSPECTIVE TOWARD UNRECORDED DIVORCE IN ACEH, INDONESIA ${ }^{1}$
}

\author{
Jamaluddin*, Nanda Amalia** \& Laila M. Rasyid***
}

This article aims to explore the perspective of a judge at the Sharia Court, ulama (Islamic traditional scholars), the parties litigant, tuhaadat (indegenious elders), as well as the public related to the implementation of Article 39 of the Marriage Act which stipulates that divorce can only be done in the presence of the trial-compared with the increasing number of divorce that occur outside the court or in other terms connotated as "cerai liar" (unofficial divorce) or divorce that is not recorded in the court (unrecorded divorce). According to the state, divorce law must involve legal institutions and judicial authorites, but for some people-divorce is a domestic matter-that does not need the state to involve. Reality shows that unofficial divorce would cause hardship for the parties, especially women in the terms of civil registration. It is almost certain that in every divorce imposed by a husband against his wife outside the court, her husband does not fulfill the obligation for his wife as a result of the divorce, such as nafkah idda (divorce stipend), nafkah madiyah (judicial stipend), mut'ah (divorce alms), and the division of shared properties.

INTRODUCTION

I. Notes ON METHODOLOGY AND DATA ANALYSIS

II. DIVORCE LAW IN INDONESIA 651

III. SHARIA COURT JUDGE's PERSPECTIVE ON UNRECORDED/UNOFFICIAL DIVORCE 652

IV. SOCIETAL PERSPECTIVE ON UNRECORDED DiVORCE ............................656 CONCLUSION 664

\footnotetext{
${ }^{1}$ This study was finance by Directorat General on Research and Community Service, Year 2014. The authors would like to thank DITLITABMAS DIKTI. A part of this paper has been presented in the $5^{\text {th }}$ Biannual International Conference on Aceh and Indian Ocean Studies (ICAIOS) UIN Ar-Raniry Campus, Banda Aceh, November 17-18, 2015 under title "Cerai Liar dalam Masyarakat Aceh: Studi Sosio-Legal tentang Hukum Perceraian dalam Perspektif Masyarakat, Ulama dan Hakim Mahkamah Syar'iyah" (Illegal Divorce in Acehnese Society: A Socio Legal Study on Divorce Law as Perceived by Society, Islamic Scholars and Judges of Islamic Court.” A profound acknowledgement we should address to Al Chaidar who has translated this article from Bahasa Indonesia for his meticulous effort. * Jamaluddin, a Professor at Faculty of Law and Lecture at Graduate Program in Legal Studies, Faculty of Law - Malikussaleh University, Aceh, Indonesia. Research fields: Family Law and Customary Law.

${ }^{* *}$ Nanda Amalia, Lecture at Graduate Program in Legal Studies, Faculty of Law, Malikussaleh University, Aceh, Indonesia. Research fields: Women and Legal Justice System \& Contractual Law.

*** Laila M. Rasyid, Lecture at Graduate Program in Legal Studies, Faculty of Law, Malikussaleh University, Aceh, Indonesia. Research fields: Customary Law.
} 


\section{INTRODUCTION}

This research moved from the data presented by the various print media $^{2}$ and statistical data presented by the Supreme Court through its website ${ }^{3}$ related to the increasing number of divorce rates from year to year. Aceh was specifically chosen as a test site considering its existence as the privileges province which imposes Syariah Islam and considering the phenomenon of the increasing number of divorce rates in the community. On January 12, 2010, local news website Serambi Indonesia reported that there were 19 districts/cities in Aceh which had a high divorce rate and the contested divorce dominated all the cases. Statistical data presented by the Directorate General for Religious Courts also showed an increasing number of verdict against divorce cases in Aceh. In 2008, there were 765 cases of thalak divorce and 1.598 contested divorce filed by wife. In 2009, there was a decrease in the number of thalaq divorce as many as 711 cases but contested divorce filed by wife cases increases with the number 1,754 . In 2010 and 2011 also showed an increase number, there were 850 thalaq divorce cases and 2,034 contested divorces filed by wives, and in 2011, there were 1,011 divorce cases and 2,408 contested divorce filed by wives. ${ }^{4}$

Preliminary studies has been conducted in early January 2012 dicovered, there were 11 (eleven) divorce cases filed by women to the sharia court Lhokseumawe because they had previously been divorced by her husband outside the court. In many cases, the petition for divorce filed by women was forced to, because they have to get legal certainty on the status before the state. To confirm this, the authors interviewed one of the judges on the sharia court Lhokseumawe and got information that approximately 80 percent of incoming divorce cases are because the woman has been divorced at home. ${ }^{5}$

The increasing number of divorce rates filed to the Court of Religion and Sharia Court ${ }^{6}$ in Aceh is a phenomenon that can not be denied and

\footnotetext{
${ }^{2}$ See more, www.ccde.or.id/index.php?option=com_content\&view=article:isteri-ramai-ramai-gugatcerai-suami; and on the issue of high rate of divorced, see, www.lintasberita.com/Nasional/.../AngkaPerceraian-Naik-100-Persen; www.detiknews.com/read/2011/08/04/.../menekan-angka-perceraian?...; Angka Perceraian Pasangan Indonesia Naik Drastis 70 Persen_...www.republika.co.id.

${ }^{3}$ Further more on this issue, see, http://putusan.mahkamahagung.go.id/ditjen/agama/; www.republika.co.id (last visited Jan. 24, 2012) and http://www.badilag.net/statistik-perkara/10119informasi-keperkaraan-peradilan-agama-tahun-2011.html.

${ }^{4}$ Source, http://www.badilag.net/statistik-perkara/10119-informasi-keperkaraan-peradilan-agama.

${ }^{5}$ Interview with Judge FH on 21 January 2012.

${ }^{6}$ Sharia Court (Mahkamah Syar'iyah), usually abbreviated as M. Sy, is a formal religious court in Aceh. Sharia Court was established in 1992 to conduct religious related process of law in Aceh Province as a part of national legal justice system in Indonesia.
} 
becoming the background of this study. The implementation of Article 39 of the Marriage Act becomes ineffective when associated with the protection of women's rights as a result of the divorce. There were implication due to the article 39 (1) for women in particular, when the divorce has been pronounced by her husband not before the trial ${ }^{7}$ and personally based on her religious beliefs, she considers herself divorced - but on the other hand, the state does not recognize this kind of divorce.

Legal certainty to the status of a wife who has been divorced outside the court can only be obtained through the judge's decision, but the reality in the society inficates different situation. According to a report on the legal aspects of divorce out of court - conducted by SMERU Research Institute and Indonesian Supreme Court - showed that nine out of ten female heads of households can not access the court for their divorce case. The study also found that the court fees and transportation costs to court is still a major obstacle for women. ${ }^{8}$ In Aceh, the conditions are not less than those shown in SMERU's studies. This condition is exacerbated by the lack of legal understanding of society - particularly women - related to the legal protection which can be provided by the state through religious courts to the fulfillment of women's rights after divorce. Tuha Peut - as an apparatus of vilages - had not been able to demonstrate its existence as executive officers of the Majelis Peradilan Damai Adat Aceh ${ }^{9}$ (Aceh Judicial Council of Indigenous Peace), they should be able to facilitate the fulfillment of women's right after divorce. This condition is believed to be positioning women in a weak condition, not only because of the legal uncertainty over her status but also because of the condition that forces her to become the head of the family and meet all the needs of the household. Not to mention the oblique view of the neighbours of the widow who was divorced by her husband.

The debate over legal certainty to the status of a woman who has been divorced outside sharia court appears, both religious law and state law. This

\footnotetext{
${ }^{7}$ Cf, ABD. Rahman GHAZALY, FiQIH MunAKahat 205 (Kencana, Jakarta 2003) “...that according to Islamic law, does not make it right to divorce in the hands of others, either someone else's wife, the witness or the Court. In addition to that right of divorce is in the hands of the husband but the majority of Islamic legal scholars found that divorce with playfulness (not really intended to do so) is deemed valid, it is based on a saying of the Prophet Muhammad (hadith) narrated by Imam Ahmad, Abu Dawud, Ibn Majah, and Tirmidhi and Imam Hakim validated three cases, in fact deemed true and play the game (also) holds true, namely the problem of marriage, divorce and ruju' (reconciliation)."

${ }^{8}$ Source, http://www.pa-sangatta.go.id.

${ }^{9}$ Majelis Perdamaian Adat Aceh (Aceh Judicial Council of Indigenous Peace) has been promoted by the Government of Aceh as a part of Aceh previleges’ program.
} 
debate is not only related to the conditions of legal pluralism ${ }^{10}$ and showing the weakness of this plural legal system ${ }^{11}$ but also the formalization of sharia law made by the Sharia Court against legal provisions of talaq (divorce). As well, their thoughts on the importance of state intervention protect women - specifically wives - for her rights. To examine the phenomenon as it has been described previously, this study seeks to discuss the descriptive differences between the public and the judges on the Syar'iyah court about unrecorded divorce. The study found that a divorce considered as "lawful" is interpreted differently in each scene of the case, the incident and anyone who handled the case.

\section{Notes ON METHODOLOGY AND DATA ANALYSIS}

This paper is based on the fieldwork we undertook in six districts and cities in Aceh province which are the district of Nagan Raya, Pidie, Bener Meriah, Bireuen, North Aceh, and Langsa in 2014. These six research areas have been deliberately with some consideration, namely, (1) The six regions are considered to represent a geographic area of Aceh province. (2) the increasing number of divorces - recorded and unrecorded divorce - in the region over the years - as in North Aceh and Pidie Langsa. Respondents were determined by purposive sampling. Respondents were drawn from each district/city - they were husbands/wives who fulfill their divorce before the court and they who does not fulfill in to the court. While the informant was determined by the selection criteria people considered the most understand the problems studied, including: Chairman of the Consultative Council of Ulama (MPU) Aceh; Chairman and 6 member Board of MPU at District and City level; Chief Justice and Chief Justice Syar'iyah Aceh Syar'iyah at 6 Regencies and Cities; Syar'iyah Court judges; Imuem Mukim (local religious clerics), Imuem Chik (senior village clerics), Ulama Dayah (traditional Islamic scholars), Keuchiek (head of village), Imuem Gampoeng (village cleric), and community leaders.

This study is a qualitative research by applying normative and empirical approaches. This study used two methods of data collection, the

\footnotetext{
${ }^{10}$ Arskal Salim, Legal Pluralism in Indonesia : The presence of Islamic Law in National Laws and Regulations, HARMONI 15, 15-34(2008), October-Desember Issue.

${ }^{11}$ Weak legal pluralism is interpreted as a concept of political authority (the state) that recognizes more than one legal systems to apply formally for groups of different communities. While strong legal pluralism refers to the existence of more than one legal systems that each is independent and its entry into the community is not dependent on recognition or endorsement by a political entity. In this concept, between each of the legal system have the same position, there is no hierarchy higher or lower, between one another.
} 
collection of primary data and secondary data. Primary data collection (primary sources) was performed by using in-depth interviews with Syar'iyah Court judges on the location of the research as well as the parties -husband and wife-and the tuha adat (Elders Indigenous Law Practitioners) litigants and the general public. Observations on trial in the sharia court and observation of the conditions surrounding the research area as well as the condition of the divorce issues outside of court that is felt by the parties are also used as part of data collection. Focused group discussion also conduct, which aims to get an overview of the community perspective and sharia court judges and scholars to the protection of women's rights as a result of unrecorded divorce.

\section{DIVORCE LAW IN INDONESIA}

Before discussing further to the Indonesian legal regulation relating to divorce, the following sections will be discussed in advance about the dissolve of marriage according to Islamic law. It needs to be understood that divorce is just one of the four (4) things to decide marriage in Islam. According to Islamic law, marriage may dissolve due to several possibilities as follows: ${ }^{12}$ (1) Due to the death of one of the couple, both husband and wife; (2) Due to the breakdown of marriage at the discretion of the husband by reason and expressed his will with certain words. Divorce is commonly known as talaq. Islamic law specifies that the right of talaq is dropped on the husband and the husband can use this absolute right anywhere and anytime, without the need to tell or to ask permission to anyone. In fiqh, the divorce situation as marriage is a private matter and therefore does not need to be regulated in the public. (3) The dissolve of a marriage at the discretion of the wife, while her husband does not want this marriage break up. Marriage break condition is referred to as khulu. The will to break the marriage which was delivered by his wife in a certain way is received by the husband and continued with his words to break the marriage. (4) Disconnect marriage can also be caused by the will of the judge as a third party after noticing something on her husband and/or wife that signifies no failure by the marital relationship continues. This condition is referred to as fasakh.

Talaq is litterally interpreted 'to release' or 'to free'. The statute is makruh, because it includes the acts that although justified however unpopular and hated by the Prophet and the God, Allah SWT. Husband to his wife who dropped a talaq must meet several terms and conditions, namely: (1)

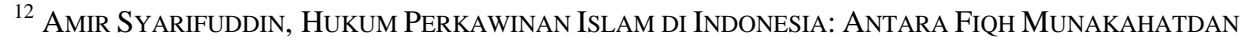
UNDANG—UNDANG PERKAWINAN 227-228 (Kencana, Jakarta 2014).
} 
a husband who pronounce talaq must necessarily be someone who has grown, healthy minds, conscious and on his own will; (2) newly divorced women still is the wife or a women who still married to him, and a woman who are in a state of talaq raj'iy; (3) the utterance sighat (the pronounciation) of talaq.

In Indonesia, the dissolving marriage case also obtain settings, not just in the Marriage Act, but also in Government Regulation No. 9 Year 1975 as the implementing rules of the Marriage Law and Islamic Law Compilation (KHI, Kompilasi Hukum Islam). Article 38 of the Marriage Act regulates marriage breakdown divided into three (3) things: a. death, b. divorce and c. the court's decision. This provision is reaffirmed in Article 113, which reads "The breakdown in the marriage that caused by divorce occurred because of talaq or by divorce lawsuit”. Talaq own meanings set out in Article 114 which states KHI "divorce is the husband pledge before the trial courts that became one cause of marriage breakdown in a manner referred to in Article 129, 130 and 131 of KHI”.

Relevant provisions of divorce according to the Marriage Act under Article 39 which states: in Paragraph (1) Divorce can only be done in front of the court after court concerned tried and did not work to reconcile the two sides. In Paragraph (2) To make divorce there must be sufficient grounds, that between husband and wife was not going to live in peace as husband and wife. In Paragraph (3) The procedure for divorce in front of the court stipulated in legislation. Divorce in court-according to the majority of Islamic scholars-not become a necessity, however, the law in Indonesia has declared itself as a must as provided for in Article 39 Paragraph (1) of the Marriage Law. This provision is expressed also in the formulation of the same paragraph in Article 65 of Law No. 7 of 1989 on the Religious and Article 115 Compilation of Islamic Law or KHI.

\section{SHARIA COURT JUdGE’s PERSPECTIVE ON UNRECORDED/UNOFFICIAL DIVORCE}

This study believes that the existence of the Syar'iyah Court as an institution through judges plays a central role in managing conflict resolution at the family level through the judicial process. To that end, the discussion on the presence of a judge at the Syar'iyah Court as an agent of justice would not be separated from discussing the attitudes and the behavior of judges and their gender's case sensitivity in handling cases related to family conflicts. Arskal Salim ${ }^{13}$ specifically documented gender

\footnotetext{
${ }^{13}$ Arskal Salim, et al., Demi Keadilan dan Kesetaraan: Dokumentasi Program Sensitivitas JENDER HAKIM AGAMA DI INDONESIA 53 (Jakarta : PUSKUMHAM-UI and The Asia Foundation 2009).
} 
sensitivity among religious judge at the Syar'iyah Court in Aceh, West Sumatra and South Sulawesi. This study found that gender analysis could help judges to solve the problem of unrecorded divorce. Gender analysis will be studied in depth which is the most disadvantaged in the event of legal uncertainty due to the legal dualism, positive law on the one hand and religious laws on the others. It is certain that the most disadvantaged are women because their legal status became uncertain before the state. This study also discusses the discourse of sanction for a husband who gives divorce without judicial process.

This study believes the importance of legal certainty over the status of divorced wives. However, there were problems associated with the trial procedures that must be faced by women. Most judges consider that the main reference in making legal consideration on divorce cases is what revealed in the court proceedings and it should be based on legal provisions in force in the courts. This condition-how the judges made their considerations - still relies solely on statutory provisions. The provisions of the Marriage Act, which states that divorce, can only be done through the Syar'iyah Court approved by all the judges who become informants in this study. There is criticism to religious courts in Indonesia-as stated by the editorial column of Majalah Peradilan Agama ${ }^{14}$ —delivered by Tim Lindsey (2012: 14), that Islamic justice in Indonesia is only at the level of symbols, not the contents. This can be proved then from divorce judgments that it is tantamount to a general judicial decision, and even in his view the judgment identical to the product trial in a secular country like Australia. It can be shown from the lack of in-depth studies on the most authoritative sources such as Al Quran, Hadith and Fiqh (Islamic jurisprudence) in the religious court decision as was also seen in the decision of the Syar'iyah court.

Concerning the divorce matters, Arskal Salim ${ }^{15}$ have demonstrated the existence of two kinds of divorce: the first, filed divorce and acknowledged that the divorce is yet legally happening because it does not meet the terms and conditions of legitimate; and the second, the divorce which recognized has occurred and the pair or the plaintiff went to the Islamic Court to obtain administrative approval. Although not stated explicitly, this study found a third variety of forms of divorces - the figure of this kind - could be higher than the official court statistics presented by the Sharia Court in Aceh and Religious Courts in Indonesia. This is the unofficial, unrecorded or illegal divorce, known as "cerai liar", which is in fact accepted by the parties and is

\footnotetext{
${ }^{14}$ For futher details, see, Majalah Peradilan Agama, 2, in the editorial section 3 (SeptemberNovember 2013).

${ }^{15} \mathrm{Ibid}$, at 59 .
} 
believed to disconnect the marriage bond between husband and wife but it is not registered to the court.

Based on the interview at 6 locations of the research, the authors see there were common view of the judges, that they based their understanding of the provisions of Law No. 1/1974, PP 9/1975, and Compilation of Islamic Law (KHI) - they do not recognize divorce outside of the sharia court. It is interesting for further discussion, whether this understanding motivated by the presence of sharia court? So, they could not make their sentence contrary to the legislation? If so, then this indicates a condition in which a judge would only be a mere mouthpiece of the law (in Dutch: spreekbuis van de wet, or in French: bouche de la loi), and at the end, how the principle of ex aequo et bono can be applied? Why the judge did not use this principle to achieve justice?

The following section of this paper will be presented excerpts from the interview judges in this area of research related to understanding and experience in handling illegal divorce cases. One of the judges in the sharia court, Pidie, stated that “... Many divorce cases are filed with the sharia court Pidie but the parties were divorced outside the court, as if they had not submitted the case to follow the trial divorce again, even just to ask the administrative records to validate their divorce. But the court still encourages the parties to divorce proceedings in court. For them that are already divorced outside of the court and can not be reconciled, the trial seems only a formality process, but inevitably judges must performed mediation for the parties." 16

He also explained that “... Although the party who filed the divorce case has been dropped divorce out of court, the sharia court does not consider it as legitimate divorce, such a pronouncement was merely the cause of the quarrel and the parties wanted a divorce.” According to him it is in line with the principle held by Syar'iyah tribunal judges namely reconciling the parties who want to divorce as an effort to prevent the occurrence of divorce. In line with the views as stated previously, the deputy of Bener Meriah Sharia Court ${ }^{17}$ also revealed that the sharia court never considered their first divorce or divorce even three who had spoken out of the court. He believes that a divorce can only take place in front of the court, as married to the rules of law the divorce must be based on the rule of law.

Related to the views of people who adhere to the jurisprudence of divorce (fiqh thalaq), for him, jurisprudence is not a law, it is only a

\footnotetext{
${ }^{16}$ Interview with AriefIrhami, a judgeat Sharia Court Pidie, 16 May 2014.

${ }^{17}$ Interview with Taufik Ridha, Deputy Head of Sharian Court in Bener Meriah, 15 August 2014.
} 
discussion of the Muslims law. However, if the jurisprudence is included here among the forms of legislation then as a judge, he will enforce it as law. A similar view was also expressed by judges in the sharia court of Meulaboh, “... that what is embraced by the public in the case of divorce, the KHI and the Marriage Act should also be considered as jurisprudence because they are the result of human studies and should be obeyed by the people."18

This condition would show us, there is still a lack of attention of the state to provide maximum access for women to obtain legal certainty and justice. On one side, this condition also indicates that judges have no creativity in performing legal discovery in its decision. The judge's ruling or sentence should be progressive, the decision should not in a various formal legalistic which is able to maintain an order only, but the sentence would have to be able to encourage improvements in the community and build social harmony in the society. This progressive ruling would need to be done by sharia court's judges in handling cases involving family conflicts as divorce cases. Judges need to have the moral courage to break through the various screens that may exist when a statutory provision is contrary to the public interest, decency, civilization and values that live in the community.

What caused this to happen? Maybe this was due to the judges' concerns of examination process they will face if their verdict contrary to the statutory provisions. This is stated by one of the judges on the sharia court of Lhoksukon, “... instead we do not understand what was desired by the litigants, but as judges we are bound by the statutory provisions. The provision stipulates that divorce can only be done after the judge is not able to reconcile the two sides through the trial procedures. This regulation made by the state with the aim of providing protection for people, especially women. However, if Aceh provides special arrangements for these through local regulations then, of course, as a judge, I will also comply with the special regulations." ${ }^{19}$ For some people in Indonesia-justice and fairnessmaybe just merely wishful thinking, but in the context of the court and its decision, judges have a great role to build a logical argument and intertwine with rational considerations in the perspective of common sense. This context should be understood that the judge is not to formulate a rule of construction to match the case or problem with the logic of a rule only. The judge should make a legal reasoning with various existing technical decision

\footnotetext{
${ }^{18}$ Interview with Bahtiar and Tarmidzi, head and deputy of Sharia Court in Meulaboh, 11 August 2014.

${ }^{19}$ Interview with Azis, Judge of Sharia Court in Lhoksukon, 26 May 2014.
} 
which will reflect fairness. This condition is presumably also the mandate of Article 5 of Law No. 48/2009.

In the context of unrecorded divorce, then presumably the judge must be able to produce a progressive divorce decision, which oriented on justice and fairness. The decision may consider the specific conditions experienced by women due to sociological construction that inevitably they have to face. The decisions should consider the rights of wife and children after divorce, even when divorce has dropped outside sharia court proceedings. The progressive decision need to consider the economic capacity of husbands, so that even if not required by the wife, the wife's rights as a living postdivorce 'iddah and mut'ah can be directly charged to the husband, as well as child protection. Children living allowance should always be considered in accordance with the ability of the parents. So when the husband has the economic capability or wealth, the children's needs can be directly charged to husband through the verdict, although the wife does not request it. At least, through the progressive divorce decision, the judge has sought to make laws for the benefit of man, and not vice versa. Through its decision, the judge has given the legal protection of the rights of women and children after divorce.

\section{Societal Perspective ON UnReCORded DivorCE}

This study considers it is important to explore what is understood by the society related to the divorce, especially their views on unrecorded divorce and the rights for both parties after divorce. The society in this study is the litigant parties, both of which have filed a divorce without the divorce process before the sharia court-nor the parties who filed the divorce case before the trial. In addition, people who were interviewed are the general public who have heard or knew the practices of "talaq's imposition"20 by the husband over the wife without proceedings in sharia court. Geuchik's understanding, as well as the tengku imum and the tuha peut of village, about divorce practices undertaken by communities in surrounding villages will also be an important part and will enrich this article.

Based on information from respondents and informants, the study found many women in each of the research sites are already divorced by her husband without court proceeding. This condition, if associated with the Marriage Law, PP No 9/1975 and KHI are certainly very contradictory. The

\footnotetext{
${ }^{20}$ The term "jatuh thalak" (fallen a thalak or fallen a divorce) is a term that is commonly found in people of Aceh, to describe a condition in which the husband had been pledged or thalak signaled to his wife that have been enacted "law" of the woman, i.e. divorce.
} 
dissolve of a marriage relationship between husband and wife in the provisions of the Marriage Act can be caused due to various reasons ${ }^{21}$. These conditions would also be the reason for the divorce between the parties, although the reasons are the most dominant in almost the average location of the study due to a third party, namely the existence of the marriage the husband with other women as well as the reasons irresponsible husband on the economy of the family. Associated with not filing this divorce case before the trial in the sharia court motivated by a variety of reasons, including: (1) the consideration or feeling of no need to have a divorce certificate, (2) family considerations, and (3) access to Syar'iyah court is burden some, in terms of cost, the distance between home and the court and the trial procedures are considered complex. Women's life in Aceh is also experiencing the problems that quite a lot, both domestic issues and social problems. In general, people still have a negative view of a couple that decided to divorce. For society, the divorce is bad, evil; hurt feelings of one or both couple and detrimental to the children and families of both parties. One judge in Langsa said divorce issues is "a matter of the heart". ${ }^{22}$ When the wife wants a divorce and proposes the divorce against her husband, it is seen even worse than that meted divorce husband to wife. This happens because there is still the belief among the society that the husband's position is religiously and culturally higher in rank than wife. Interviews that researchers do in Nagan Raya find information from one of the women, Mrs Henny ${ }^{23}$ who has been divorced by her husband without getting a divorce certificate. She explained the reason for the divorce because her husband had remarried without her permission and moved to the Southeast Aceh region. During this abandoned, she neither asked her husband for certificate of divorce; nor proceed it to the sharia court. She did not make the absence of a divorce judgment because she believed that the statement of divorce submitted by her husband has become a verdict for her legally by sharia law. In fact, after this period she got married again to a

\footnotetext{
${ }^{21} \mathrm{KHI}$ Article 116 states that divorce can occur for a reason or reasons : a) one party commits adultery or become drunks, compactor, gamblers and others that are refractory, b) one party leaving the other side for 2 (two) years row without consent other party and without valid reason or because of other things beyond their means, c) one party gets a prison sentence of 5 (five) years or more severe punishment after the marriage takes place, d) one of the parties committed atrocities or severe persecution endangering the other party; e) one party gets disability or disease as a result are unable to perform his duty as a husband or wife, f) between husband and wife continuous disputes and quarrels , and no hope of living in harmony again in the household, g) violates husband on taklik talaq h) conversion or apostasy which led to the non-harmony in the household.

${ }^{22}$ Interview with a Judge of Sharia Court in Langsa, 12 June 2014.

${ }^{23}$ Interview with Mrs. Henny, in Nagan Raya, 9 August 2014.
} 
married man as his second wife. ${ }^{24}$ Her second marriage was conducted in the presence of local village qadhi (traditional judge) and did not last long, the reason is that the husband is often having an affair with another woman. At this second marriage, her marital relationship with her husband ended up (also) only with a sheet certificate of divorce signed by her husband and left at home without direct consent of the wife. Until now the husband never comes home and never gives her anything good living for herself and her rights during the waiting period (iddah).

More or less the same conditions faced by Nurul Asriah, ${ }^{25}$ She was divorced by her husband by pronouncing directly a thalaq one (thalaq satu). Court proceedings were never made at all, either from her or from her husband. She said that, for many times she had asked her husband to proceed the divorce to the sharia court but her husband always replied and said "... There must not be a letter (divorce certificate), if you want to get married just do it." ${ }^{26}$ Besides of the talaq pronounced by her husband, she also believes that her marriage has ended because several conditions: (1) the fact that her husband has returned her to her family_which sociologically -believes as a form of divorce, (2) her husband returned to his parent's house, (3) her husband no longer provides her for any living allowance.

Other thought expressed by Ratna, ${ }^{27}$ she was divorced from her husband and got a certificate of divorce signed by her husband but did not submit it to the sharia court because of the demand from his husband and her family. According to the family, even they divorced but the relationship between families should be protected. It could be different, if, Ratna proceeded the divorce to the sharia court. This condition would be a reflection that for some society, taking care of certificate of divorce to sharia court strap can cause the loss of family harmonious relationship of both parties who had previously been established. This condition raises the following question: What's about the certainty of the legal status of women?

\footnotetext{
${ }^{24}$ The conditions, second marriage or a third marriage of a woman in concealment or marriage that is not recorded at KUA (The Office of Religious Affairs) - usually caused by several conditions. The major condition caused of the husband who is still bound by another marriage and does not apply for a permit of polygamy, and the other reason is that quite often revealed because of the absence of divorced certificate.

${ }^{25}$ Interview with Mrs.Nurul Asriah, of Gampong Guha Ulueu Aceh Utara, 27 May 2014.

${ }^{26}$ Similar statement also expressed by Mrs. Marzuani when her husband asked to take care of certificate of divorce and did not go to meet its demands (interview date in Pidie, dated May 15, 2014). She has been abandoned by her husband approximately 18 (eighteen) years, since 1998 until now, no certificate of divorce and a living iddah. He never asked village officials to create a certificate of divorce but by the village was not granted by reason of the absence of their authority to issue similar. The village apparatus asked the concerned to keep taking care of divorce papers to the court.

${ }^{27}$ Interview on 11 August 2014.
} 
What's about the rights that should be held by women in post-divorce? Isn't it becoming the main concern of the community?

The most common strategy in divorcing a wife is by unilateral letter written by husband from a remote place. These written letters-usually used by a unilateral divorce from the man or husband to his wife-well known by the local village officials or not, may be a common practice among people of Aceh. For women, it is becoming sort of grip, that her husband no longer bound her. As Henny's experience as mentioned above, several other female informants also experienced similar conditions. One unforgettable thing experienced by Mrs. Lisnawati was when she underwent her marriage with her husband only for 3 (three) days. At the day 4, her husband returned to his parent's house and said nothing to her. He never gave any reason why he never returned to Mrs. Lisnawati's home. But the main reason that bothered her and caused this condition was something much ado about carnal and psychological factors. ${ }^{28}$ Her husband never once pledged divorce for her, but a few months after, she received the envoys from her husband bringing a letter signed by her husband and stating a divorce for her. ${ }^{29}$

Up to the time of the interview, their marital relationship had broken up approximately for 6 (six) years, and she never initiated to proceed the divorce or the annulment of marriage to the court. She thought she never needed the certificate of divorce, until she met a man and he wanted to marry her. This man asked her a divorce certificate and provided her a sum of eight hundred thousand rupiah (Rp. 800.000, -) to apply to the court. Unfortunately, the trial process has led her disappointed and to think for not continuing the process. She got an 'awkward' experience dealt with the court and she felt the judge asking her for questions she did not understand. At the peak of this drama, Lisnawaty told the trial "... If it is so difficult and complicated to issue a sheet of certificate of divorce, I would not need to attend the hearing again.” At that time, the judge responded her by asking, “... so, do you want to undo the lawsuit?” And this question was addressed directly by Lisnawaty to convey that she was not going to continue this process anymore.

Apparently, the proceedings in the sharia court is still considered

\footnotetext{
${ }^{28}$ At the time of the interview, Mrs. Lisnawati said “... it seems like he was embarrassed, because he can not do for the 'it'. Although it does not convey the specifics, presumably researchers understand there is the possibility of the husband is not able to sexually satisfy spiritual needs of husband and wife, and psychologically it is quite a burden for him to decide to leave home. Several times the wife has tried to foster communication and convey his request to invite the husband seek treatment but never addressed by the husband".

${ }^{29}$ To confirm this, the researchers also find Geuchik Gampong Uleu Guha, interview dated May 27, 2014.
} 
complicated for some people even when they feel that actually they need the assurance from the state that is represented by sharia court to issue a divorce certificate. The above descriptions provide an overview of how women deal with divorce pronounced by her husband and do not get the assurance of their marital status before the state.

This study also finds another experience related to the unregistered divorce. We interviewed Huliyati ${ }^{30}$ who facing the same condition but because of different reason. Personally, she claimed that she-no longerhas any relationship with her husband, especially since she decided to expel the husband from the house for being caught having an affair with another woman. Since then (approximately 3 years ago) many times she asked her husband to proceed the divorce papers to the sharia court; but this request was not addressed by the husband for reasons that he did not want to split up with Huliyati. Although the husband, in his testimony did not want to divorce, but since three years ago, her husband also never again provided living expenditures for Huliyati, therefore she was sure she will would not be back again with her husband. She herself objected to bringing the case to sharia court due to the cost issue. She had thought of her inability to provide a court fees and a travel cost to the court. She also considered the problem of the distance to the sharia court that she thought far away and costly. However, she expressed her desire to be able to get a legal certainty and justice from the state with no further complicated things. In her expression she said,

... If there were a free trial to be able to release a certificate of divorce, it would be better. Why does the government cannot assist people like me? It was clear I was aggrieved. So far I bear the cost of household spending, but it turns out my husband betrayed me, why do I have to take care of divorce papers?

Another experience is expressed by Riyana. ${ }^{31}$

... Indeed, prior to trial, the husband had never divorce me, but at that time I also intend to divorce him, but after I knew he (husband) want to re-marry again to another women, I cancel for my plan to file the divorce into the sharia court and he (her husband) eventually raise this case to court.

In further explanation she said that when the proceedings in sharia court she initially demanded a certain amount of money as a nafkah iddah (stipend during 3 months waiting period), but because the husband said he was not able to fulfill it, he made the decision to no longer demand it, solely for the trial can be completed and later she got a divorce certificate.

\footnotetext{
${ }^{30}$ Interview with Mrs. Huliyati in North Aceh, 27 May 2014.

${ }^{31}$ Interview with Mrs. Riyana, in Pidie, 15 August 2014.
} 
We believe that an exploration related to public perceptionparticularly the parties litigating divorce out of court-not comprehensively without displaying information from the husband. We met two informants and one ${ }^{32}$ of them said that he has stated the divorce to her wife not clearly by talaq but initiate the talaq by expressing such as "... kalau udah gak mau nurut lagi apa kata saya, ya sebaiknya kita cari jalan lain (if you don't want to obey me any more, than we should find another way)". After stating this to his wife, he asked 2 (two) ulama (scholar) for their opinion in religious viewpoint. It was reflecting the talaq decision or not. One of the ulama stated that it had decided cues such as marital relations while the other ulama suggested otherwise, he assumed that similar gesture was not yet decided the marriage. Finally, after praying istikharah and asking god for the best decisions he should take, he decided to file the case into the sharia court. Beside spiritual reason he took his decision also based on his position as a civil servant. He believed that administrative procedure due to his status should be well managed. He also thought that it was important for him to give the legal decision for her wife, not only based on sharia but also based on the state law. He mentioned about the harmonious relations when marrying his wife and he also hoped for the same condition after divorce.

In the sharia court proceedings, he agreed that the judge did not consider his talak which he already conveyed to the wife, even one of the judges stated "... since the case was submitted to us by the court, then the provisions and regulations must follow our terms". He also followed all the procedures requested by the sharia court. He did not think that this was a heavy requirement because his goal was to find the certainty over their status. He also met the obligation to pay a living waiting period set by the court Syar'iyah fifty thousand rupiah (Rp. 50.000,-) per day as long as 3 month and 10 day for his wife.

There is a negative paradigm toward divorce which can not be separated from the general understanding of the people who think that marriage as a sacred event that is conducted under the authority of religion and government. In this position, condemnation of divorced couples can be understood as a marriage entered into sacred territory and involves all parties. In terms of impact, the divorce also has broad impact, in addition to psychological impact on children and families, divorce is also an impact on the breakdown of social order, giving the bad example for another couple, as if divorce is the only way when families are faced with their private and domestic problem.

\footnotetext{
${ }^{32}$ Interview with ZN, in Lhokseumawe, 28 June 2014.
} 
As mentioned earlier, that in this section will also be presented the perception of the general public, including geuchik, tuha peut village, mukim and other surrounding communities associated with the practice of imposing divorce outside the sharia court. It is important to understand that, the people of Aceh mostly seek and obtain justice through traditional problem solving (custom). From the fieldwork, we find that people in the community are often unaware of how disputes settled according to custom. In fact, the traditional dispute resolution with the unstructured nature, delivery orally and flows according to the community's development can provide maximum benefits to the society, especially the litigants. The development of law in Aceh and the enactment of formal legal system cause many good understanding of the traditional institutions and the general procedure of settlement process customary dispute. ${ }^{33}$

At the village level, traditional institutions occupy an important position in resolving conflict issues that arise in the community. Customs agencies have the authority to assign a divorce and may issue a certificate of divorce. Though based on existing regulations stating that divorce is invalid if performed outside the religious court. In fact, this has been mostly done by the custom agencies (such as geuchik and tengku imum) with the aim to solve the society's problem and give the benefit to the party. However, this study finds that in many divorce cases that occur outside the sharia court, the elder of local indigenous have not been able to give a decision which protects women in the enjoyment of their rights after divorce. This study also finds that for many cases the husband does not carry out his obligation to fulfill his wife's rights such as the right of the waiting period and kiswah and maskan. This fact shows that the role and functions of traditional institutions today have undergone significant changes, in the present decision customary institutions in solving the problems considered valid but unenforceable. So if there is a violation decisions agreed upon, then the punishment may be given in the form of social sanction.

Some informants said that "there are several reasons why people do divorce out of the sharia court, which are: (1) the prolonged duration of the trial, and (2) the high costs for the trial process, and (3) for some people, they were reluctan to fill the case because they still hope to get another chance in harmonious life between him and his wife" ${ }^{34}$ However, related to divorce practiced by the local community without fitting process as

\footnotetext{
${ }^{33}$ Juniarti, Strategic Role of Customary Courts in Aceh in Providing Justice for Women and Marginalized People, conference proceeding.

${ }^{34}$ Interview with Bustaman HS, one of Tuha Peut (the four senior village principal) of Kampung Keuniree, Pidie, 5 May 2014.
} 
regulated by the Marriage Act addressed differently by village officials. Largely considering that this practice is not uncommon and is not against the law in the context ofIslamic (religious) legal system. However, how the parties litigant also eventually feel the need for certainty in the form of state law divorce certificate, we got a response from Geuchik Gampong Keunireen, Pidie, he stated “... that in fact there are many litigant parties who ever had experience of divorced outside of the court and came to geuchik to request the issuance of a certificate of divorced. Facing this, he made it clear to the parties that geuchik has no authority for it and the parties are encouraged to settle into the court. ${ }^{\text {} 35}$ The same practice associated with divorce in the village also occurred in the Nagan Raya. Abu Bakar Us as Mukim in Gampong Seumot conveyed that, “... in the community we still find a lot of cases of un-official divorce. The husband just sends his wife a letter stating he is divorcing his wife". He also stated that "... the divorce (un-official divorce) usually occured due to a support to perform illegal marriages. The husband stated the divorce to his wife so he could perform another (unregistered) marriage conducted by qadhi (traditional law preacher).”36

Another viewpoint delivered by Mustafa Syamaun, ${ }^{37}$ he explained that since he served as geuchik and now is becoming a member of tuhapeut in the gampong, he have never mediated the spouse who tend to get divorce, sometimes the news came suddenly and all he knew was that the spouse had been divorced. The spouse - they do not report it and prefer to leave the village (usually the husband) and do not want to see the gampong officals so that the mediation between spouses has never happened. We also found one geuchik who explicitly expressed his consent to handle a divorce case going on in the community. He thought that if geuchik gave a discretion to address the problem at the village level, the task of sharia court is no longer heavy.

\footnotetext{
${ }^{35}$ Interview with Abu Bakar, Village Head (Geuchik Gampong) Keunireen, Pidie, on 15 August 2014.

${ }^{36}$ Interview with Abu Bakar, Mukim(Vilage Coordinator) of Seumot village,District of Beutong, Nagan Raya, 10 August 2014. A similar comment arises when researchers get to interview people in the SaraaTeube village, Langsa. That the practices of married people without KUA (Office of Religious Service) also carried by one in the village teungku (Islamic traditional scholar at village level) (when the study was conducted, tengku has passed away, but there seems to be his successor). Even when the researchers looked for a place to stay tengku, community researchers encountered immediately offered to deliver and ask whether the goal of researchers is to get married concealment. Interviews conducted by the author with Ms. May and Ms. Nur was informed that the practice of marriage concealment, as well as a certificate of divorce and fasakh (a saying of divorced statement) commonly made by the village officials, usually signed by teungku and many people who seek the religious decision of teungku, even not only the people around the area of Langsa or Eastern Aceh respectively. (Interview with Ms May and Ms Nuron June 8, 2014).

${ }^{37}$ Interview with Mustafa Syamaun, one of Tuha Peut (the four senior village principal) of Gampong Guha Uleu, Aceh Utara, 5 June 2014.
} 
At least, the court already has earned a record and first consideration from the village level due to mediation or problem's settlement. He also stated that the legal certainty of their divorce status would be more realistic. ${ }^{38}$

\section{CONCLUSION}

Based on the above-mentioned description and discussion, this study concludes that there were different perception and acceptance between the judges on the sharia court, public society and ulama related to un-recorded divorce. Judges of sharia court leaned their decision based on Marriage Act and KHI, they confirmed that the divorce without court proceeding does not have the force of law (no legal force). Therefore, the law considers it as 'never existed'. But for some society members-particularly women who have been divorced by their husbands without trial-understand that thalak which has been pronounced by the husband is legitimate-in the sense that all requirements meet the legal termination of marital relationship between the two-had dissolved. Similarly, if thalak (is) not promounced, the husband no longer fulfill his obligations - emotionally and carnally — in a certain time period, then the marital relationship between them is considered to drop out. Among scholars - both modern Islamic scholars and traditional clerics from dayah who are member of Ulama Consultative Assembly (MPU) - some believe that magnitude of divorce is valid insofar as they meet the conditions and the resulting in the dissolve of a marriage, although not filed to the trial court. Divorce experienced by Muslims in Indonesia today is still a relatively large lump because it is not based upon a growing awareness that law jurisprudence permits divorce without the involvement of the judiciary.

Meanwhile, the discussion on women's right on her legal status due to unrecorded divorce has demonstrated, there are problems overshadowing women; the problems of unequal position, the lack of bargaining power between man and women; husband and wife. The problem arises when women face their divorce status, with no post-divorce rights. Husband perception on the fulfillment of alimonies payment as a religious obligation also contributes to the loose implementation of law, as well as the economic problem faced by the majority of Indonesian people.

\footnotetext{
${ }^{38}$ Interview with Zulkifli Oka, Geuchik (village head) of Alur Pinang, Langsa, 7 June 2014.
} 